\author{
S.N. Suieubayeva ${ }^{1}$, E.S. Madiyarova ${ }^{2, *}$, G.B. Pestunova ${ }^{3}$ \\ ${ }^{1-3}$ D. Serikbayev East Kazakhstan Technical University, Ust-Kamenogorsk, Kazakhstan \\ ${ }^{1}$ Suyeubaeva@mail.ru, ${ }^{2}$ emadiyarova@mail.ru, ${ }^{3} g$ pestunova@mail.ru \\ ${ }^{1}$ https://orcid.org/0000-0002-2944-6968, ${ }^{2}$ https://orcid.org/0000-0002-9219-1603, \\ ${ }^{3}$ https://orcid.org/0000-0002-4787-4966 \\ ${ }^{1}$ Scopus Author ID: 57160209000, ${ }^{1}$ Researcher ID: AAE-8954-2020 \\ ${ }^{2}$ Scopus Author ID: 56712848600, ${ }^{2}$ Researcher ID: AAF-6844-2019 \\ ${ }^{3}$ Scopus Author ID: 57191197909
}

\title{
Study of current trends in the labour market: changes caused by digital technologies and the COVID-19 pandemic
}

\begin{abstract}
Object: To study the current state and priorities of the labour market in the digital economy and the COVID-19 pandemic.

Methods: The theoretical basis of the research is the work of domestic and foreign economists on the problems of the digitization of the labour market and the legislative and regulatory acts of the Republic of Kazakhstan. Data from the Statistical Committee of the Ministry of Economy of the Republic of Kazakhstan and the results of the authors' research have been compiled as an information base for the study. The methodological basis of the study is a systematic approach, abstract-logical, economical-statistical, monographic methods of studying economic processes.

Findings: This article contains the results of an analysis of the labour market development of the Republic of Kazakhstan in comparison with foreign countries. Employment in the digital economy and the CORONA crisis are discussed. It is noted that the faster the digital economy is implemented, the more difficult it is to manage the digital economy. Technology is becoming not only an engine for the development of new industries, but also an important social role, making a significant contribution to the solution of societal problems such as population ageing, social stratification, environmental problems and climate change. With the help of advanced science and technology emerges a «smart» society based on new values oriented to the needs of the person, flexibility, creativity. As a result of digitization, the labour market, health care, education and spatial development are changing dramatically.

Conclusions: The article discusses key aspects of the creation of conditions for the search for new forms of employment for the Kazakh economy from the standpoint of digitization. The emphasis is on the development of the digital environment in the modern environment. The content of state support of economic entities within the framework of the state program «Digital Kazakhstan» is considered. It was concluded that the changes brought about in the world economy by widespread restrictions in the context of the pandemic would lead to the search for new ways and forms of employment in the Kazakh labour market.
\end{abstract}

Keywords: digital economy, labour market, employment, digitization, pandemic.

\section{Introduction}

Today, the period of development of the world economy is commonly referred to as a crisis. Many of the areas that have been performing very well in recent years are either not fully operational or have significantly reduced their activity. On the agenda, the number one theme was the COVID-19 pandemic, the culprit of social exclusion, which led to dramatic changes in the business environment in both Kazakhstan and the world economy. The quarantine in Kazakhstan has caused significant damage to business and jobs. Thus, as of 4 May 2020, 4 million 452 thousand social benefits had been granted from the State Social Insurance Fund for loss of income during the state of emergency. Thus, 4 million 452 thousand social benefits had been granted from the State Social Insurance Fund for loss of income during the state of emergency. Of these, $3,733,800$ in the first month and 718,300 in the second month.

At present, the main success in combating the dangerous virus is that the number of cases in Kazakhstan is not growing exponentially. The World Health Organization, as well as international experts, have commended the actions taken by the Government.

\footnotetext{
${ }^{*}$ Corresponding author.

E-mail address: emadiyarova@mail.ru
} 
The support of the State during such a difficult period is very important for all citizens of the country. The Ministry of Industry and Infrastructure of the Republic of Kazakhstan has developed a mechanism to assist citizens of regions where quarantine has been introduced.

Effective small and medium-sized business is a solid foundation for the development of a country. It is entrepreneurship that can reduce unemployment, create a tax base, and strengthen local budgets. Of course, to support small and medium-sized businesses, first of all, strategic programs developed earlier come to the aid of the state.

The article is intended to confirm the working hypothesis that in Kazakhstan today, the rapid development of digital technologies in the economic and social sphere requires effective mechanisms for State regulation of employment in digital business in the context of a pandemic.

\section{Literature Review}

With international digital and informatization entering an era of greater diffusion of innovation and information through cross-border innovation and accelerated development, the digital economy has indeed become a new engine of economic growth (Curran, 2018; Gomber et al., 2018; Brignolfsson, Collis, 2019). The term «digital economy» was introduced at the end of the 20th century by American scientist Nicholas Negroponte in 1995, and its scientific content was expanded by Canadian Don Tapscott in 1997 (Gretchenko, 2018). The phenomenon of the digitization of the economy was highlighted against the background of the rapid growth in the use of Internet resources and the introduction of modern information and technology-based means of communication for the transfer of various social and economic activities, such as commerce and business, education, media, etc., in an electronic Internet environment.

Mergel, I., Edelmann, N., \& Haug, N. notes that digital transformation changes the existing bureaucratic and organizational culture, thereby improving relations with stakeholders (Mergel I., Edelmann N., \& Haug N., 2019). Warner, K. S., \& Wäger, M. define digital transformation as the use of new digital technologies such as mobile technology, artificial intelligence, cloud technology, blockchain technology, and Internet of Things to bring about significant improvements in business, improve customer service, optimize operations or create new business models (Warner K. S., \& Wäger M., 2019).

In recent years, the digital economy has advanced significantly not only in the Western world, but also in Asian countries, stimulating the integration of digital technologies and traditional economic activities (Ali et al., 2018; Taglioni and Winkler, 2016).

In the opinion of Lapidus L.V., represented in the work, the period since 2015 the world digital space is characterized as «Digital Fever», in which chaotic restructuring of business processes and transformation of business models under the influence of technologies of Industry 4.0 is taking place (Lapidus L.V., 2019).

This time is characterized by the fact that since 2017, many countries have adopted digital strategies and other programs on digital transformation, creation of competence centers of digital economy, silicon valleys, «regulatory sandbox». In this connection, the topic of the formation and development of digital forms of employment in the Republic of Kazakhstan is of particular relevance today.

\section{Methods}

A study aimed at supporting the hypothesis can be described as descriptive, making it possible to select the methods to be used.

The use of the institutional method will make it possible to assess the role of the legal framework governing the labour market, as well as State programmes in the digital economy and social sphere, in increasing employment in digital business through norms and regulations, which are its main contents.

The application of systematic analysis will make it possible to consider employment in digital entrepreneurship as a result of the functioning of the socio-economic system and to identify the factors determining its structure at the current stage of development of Kazakhstan, as well as to make cross-country comparisons.

In the formation of the theoretical basis and methodological base, the works of classical and contemporary foreign and domestic economists and specialists in the theory of entrepreneurship, anti-crisis management and the development of the digital economy were studied. The scientific literature on the problem of research has been critically reviewed. This phase involves the use of classification and systematization techniques, analogies and comparisons. It is important to observe the methods of historical and logical knowledge in order to assess economic processes in general and draw general conclusions. 


\section{Findings}

In Kazakhstan, prior to the quarantine period, a number of measures had been taken to digitize the economy, both by the State and by business entities. Much has been done in this regard. But the conditions of the pandemic have led to a dramatic increase in the digitization of the business model and the development of a new environment, the digital environment. Some segments of the economy, previously mostly existing offline, have made a «leap into the digital future» within a few months. The momentum generated by the epidemic has resulted in widespread digitization almost automatically. The external business environment has changed lightly, while changing the structure of the business itself, primarily affecting employment.

The Strategic Plan for the Development of the Republic of Kazakhstan until 2025 also provides for the growth of the economic activity of the private sector as one of its priorities, in particular, it is planned to: That the share of the gross value added of small and medium-sized enterprises in GDP will increase from $26,8 \%$ in 2016 to $35 \%$ by 2025 and reach $50 \%$ in 2050 .

In comparison, small business in the advanced economies of Europe, North America, and Asia is already at the core of the socio-economic development of these countries. For example, there are over 23 million small and medium-sized enterprises in the European Union, which account for more than half of total turnover and value added, and about $70 \%$ of the employed population.

According to the data of the Statistical Committee of the Ministry of National Economy of the Republic of Kazakhstan, the total number of the able-bodied population in the period 2015-2019 was: 8,887,600. In 2016 - 8,998,800. In 2017 - 9,027,400. 2018 - 9138.6 thousand people. 2019 - 9221.5 thousand people (Figure 1).

In $2015,8,433,300$ persons were employed in various areas of the economy of Kazakhstan. In 2016, $8,553,400$ persons were employed. In 2017, 8,585,200 persons were employed. In 2018, 8,695,000 persons were employed. In $2019,8,780,800$ persons were employed. The number of workers employed in Kazakhstan in 2019 was $6,681,500$. This represents $76,1 \%$ of the total number of employees in the economy. This figure rose by $6.1 \%$ from 2015. The number of self-employed persons in 2019 was 2,099,200, i.e. 23,9\%. This figure fell by $1.8 \%$ relative to 2015 . In the various sectors of the economy, $91,1 \%$ of the total number of self-employed persons were engaged in productive employment and 90,7 \% in 2018. Unproductive employment accounted for $8,9 \%$ and $9,3 \%$ in 2018 .

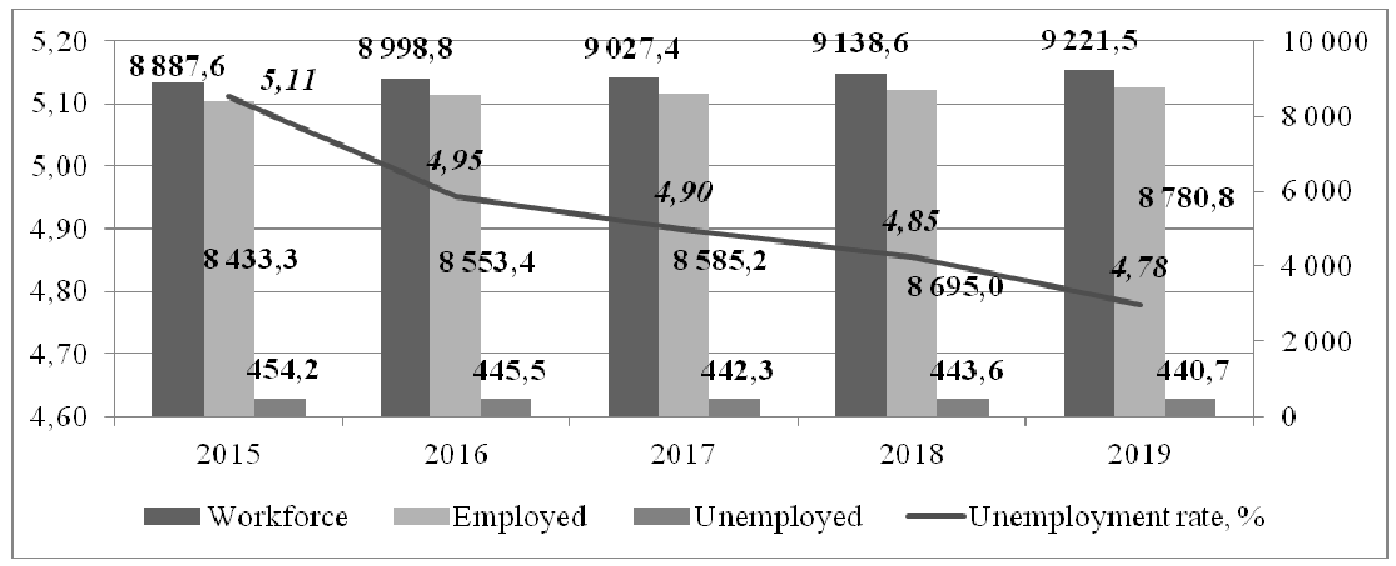

Figure 1. Laboure market indicators 2015-2019 in the Republic of Kazakhstan

Note: compiled by the authors according to the data of the source: Oficial'nyj sajt Komiteta po statistike Ministerstva nacional'noj ekonomiki RK [Official website of the Statistics Committee of the Ministry of National Economy of the Republic of Kazakhstan]

The average unemployment rate between 2015 and 2019 was $4.92 \%$. In 2019, the figure was $4.78 \%$, and in 2015 it was $5.11 \%$. In 2019, $46.4 \%$ of men and $53.6 \%$ of women were unemployed. The youth unemployment rate in the $15-28$ age group was $3.7 \%$.

According to the analysis of the Head Hunter Research Centre, over the past three years, the most demanded persons on the Kazakh labour market have been in the following professions: sales (18.2\%), accounting, management and finance (8.3\%)Administrative staff (7.2\%), information technology, Internet and telecom $(6.5 \%)$, as well as banks, investments and leasing $(6.5 \%)$. 
The top 10 cities in the distribution of vacancies are headed by Almaty, Nur Sultan and Karaganda. Few are second to Atyrau and Shymkent. Ust-Kamenogorsk, Pavlodar, Kostanai, Aktobe and Uralsk are closing the list of cities - leaders in job placement.

Among the applicants, the most sought-after professional areas are sales (12.9\%), administrative personnel $(8.4 \%)$, accounting, management accounting, enterprise finance $(8.3 \%)$, production $(5.9 \%)$. At the same time, $19.1 \%$ were in fields suitable for beginners and students. The top cities in the CV distribution are almost identical to the job placement list, but Kostanai joins the leaders.

In an article by Zamira Zholdaskyzy an analyst at the Labour Resources Development Centre of the Republic of Kazakhstan, a member of the CABAR. Asia School of Analysis from Nur Sultan, having conducted a labour market analysis for 2019, notes that the labour market in Kazakhstan today is dominated by a large number of specialists in humanitarian fields and a shortage of technical personnel, Therefore, foreign labour specialists are a temporary alternative solution to meet the needs of enterprises for highly skilled labour rapidly (ZHoldaskysy, Z., 2019). Kazakhstan has various types of unemployment, such as natural and cyclical unemployment. There is evidence, such as the lack of a job opportunity due to a mismatch in the labour market in terms of skills or qualifications.

The highest unemployment rate in 2019 was registered in the south of the country - in Almaty, Shymkent and Turkestan region (5.2\%). These regions are labour-intensive and self-employed, and the level of training of the unemployed does not meet the needs of employers. Unemployment is low in the western part of the country in the Atyrau and Mangistau regions (4.6\%) and the Csos (4.5\%). Oil production and oil and gas engineering are mainly developed in these regions. According to geographical indications, the majority of the unemployed (58 \%) live in cities of Kazakhstan and the remainder (42\%) in rural settlements.

According to the results of the research of the Joint-Stock Company «Labour Resources Development Centre» of the Ministry of Labour and Social Protection of the Population of the Republic of Kazakhstan (JSC «CRT» MLSSP RK), 71\% of the unemployed population have an education (higher education, technical and vocational education), $26 \%$ secondary and $2.2 \%$ incomplete higher education. According to researchers, $26 \%$ have higher education, $2.2 \%$ have incomplete higher education, $45 \%$ have secondary and primary vocational education, and $27 \%$ have secondary education. Women in Kazakhstan are more likely than men to work in specialties on a gender basis: (57\% for women and $53 \%$ for men). Taking into account the superiority of employed men over employed women by 332 thousand, the number of «working in a specialty» of men and women is at the same level. Moreover, specialists with higher education are more likely to work in specialties than cadres with vocational education (VE). Thus, those with higher education work in $84 \%$ of cases, while VE graduates only work in $66 \%$ of cases. A particularly important reason is the lack of work, which is most common in Kazakhstan:

- voluntary dismissal $(23 \%)$;

- no job opportunities $(22.5 \%)$;

- family reasons $(11 \%)$.

Statistics show low unemployment rates in the city of Nur Sultan (4.6\%) and Almaty province (4.7 \%). In the survey, the majority of residents of the capital, Nur-Sultan, replied that they had resigned due to the completion of their employment contract $(23 \%)$, with $21 \%$ indicating as reasons: «termination of business activity» and seasonal nature of work (21\%). Regionally, the unemployed in the city of Nur-Sultan (31\%) and in the Akmola region (20\%) are the most prominent among the «completed entrepreneurial activity» among the unemployed.

According to the experts, in Almaty province, the number of people who do not work due to personal circumstances has increased sharply (32\%), while in other regions this figure does not exceed $24 \%$. According to our country's studies, on average, $20 \%$ of the population surveyed were unemployed in the Aktyubinsk, Atyrau and West Kazakhstan regions because the organization was liquidated or the contract was shortened or terminated. In the western regions of our country, according to the results of the analysis, with the reduction of the number of unemployed persons, more than 26,000 persons are unemployed. The number of unemployed persons in the western regions of our country is estimated at 26,000 . The reason is also common among the unemployed in cities of national importance. In Mangistau region, $41 \%$ of the unemployed left their job because of housework and $27 \%$ in Almaty, owing to the predominance of women in the general structure of unemployed regions ( $70 \%$ and $69 \%)$.

In assessing the level of unemployment in the country, one cannot ignore the number of actors in small and medium-sized enterprises. Take the analysis period for 3 years, including 11 months in 2020, that is, from 2018 to November 2020 (Figure 2). 


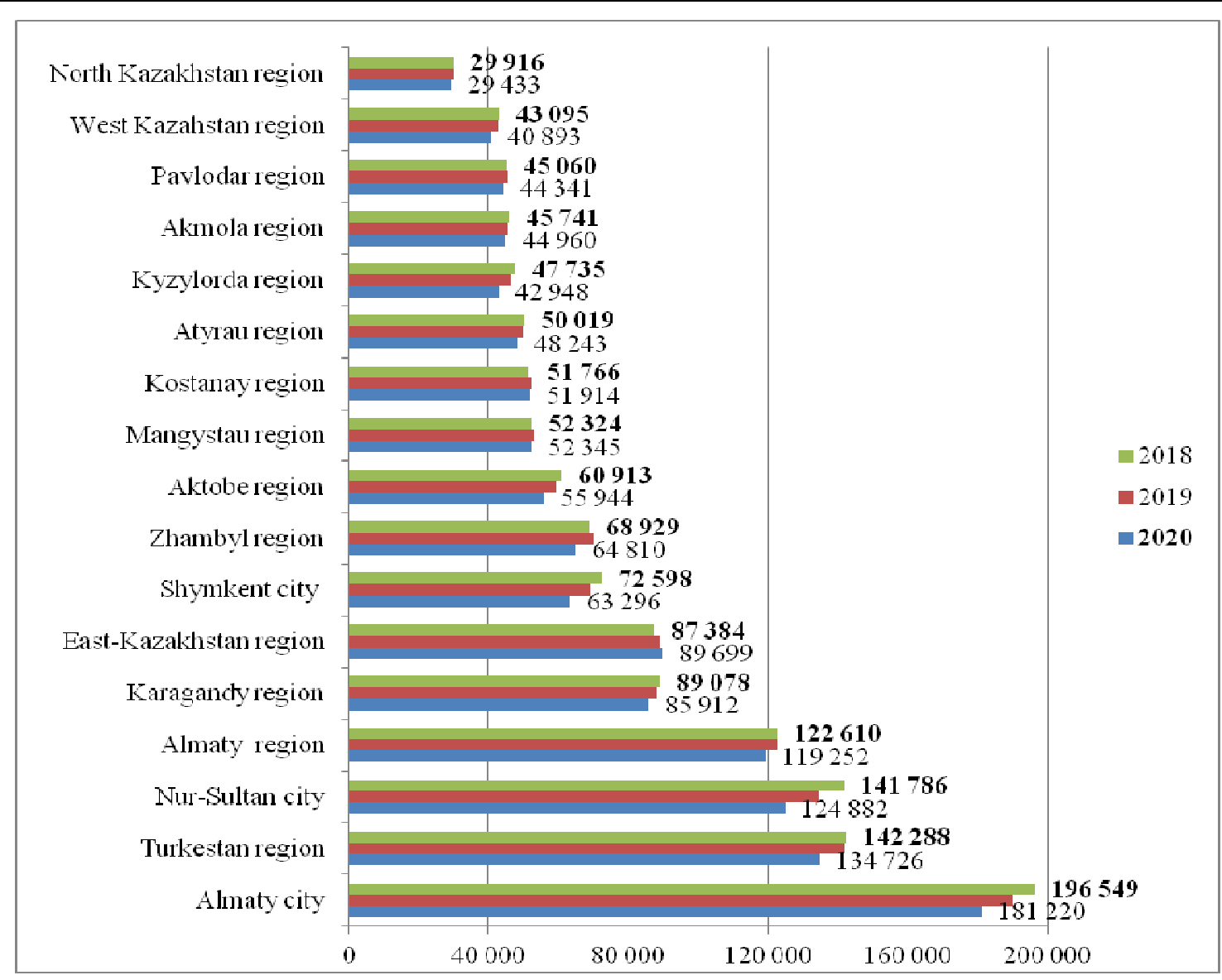

Figure 2. Number of active small and medium-sized enterprises in the Republic of Kazakhstan from 2018 to November 2020

Note: compiled by the authors according to the data of the source: Oficial'nyj sajt Komiteta po statistike Ministerstva nacional'noj ekonomiki RK [Official website of the Statistics Committee of the Ministry of National Economy of the Republic of Kazakhstan]

In three years, the number of small and medium-sized enterprises increased in the cities of Shymkent $14.7 \%$ and Nur-Sultan - $13.5 \%$, Kyzylorda oblast $-11.1 \%$ and Aktyubinsk oblast $-8.9 \%$. East Kazakhstan oblast registered a decrease of $2.6 \%$ and Kostanai oblast $0.3 \%$.

In 2019, 19,549 small and medium-sized enterprises were more numerous in the city of Almaty, 142,288 in the Turkestan region, 141,786 in the city of Nur Sultan and 122,610 in the Almaty region. In North Kazakhstan oblast, the smallest number of entities is 29,916 ; this figure fell by $0.5 \%$ from 2019. The total number of business entities in the Republic increased by $1.3 \%$ over the period 2020 , and the growth rate has not changed.

The increase in the number of subjects of small and medium-sized enterprises is facilitated by the previously analyzed indicators, the increase in the number of dismissals at one's own request, as well as by the unemployment due to: «there is no possibility to find work».

The performance of the State Programme for Employment Development declined in 2019 (Table 1). The share of the labour force with basic, secondary, general and primary education in the labour force was $14.6 \%$, which is $6.4 \%$ lower in 2018 . The share of unproductive workers in the self-employed population was $8.9 \%$, which is $4.3 \%$ lower than in 2018 .

Table 1. Results of the Productive Employment and Mass Enterprise Development Programme for 2017-2019

\begin{tabular}{|c|c|c|c|}
\hline Indicator & 2017 & 2018 & 2019 \\
\hline Growth rate of SME actors & 103,6 & 108,3 & 107 \\
\hline Unemployment rate* & 4,9 & 4,9 & 4,8 \\
\hline $\begin{array}{l}\text { Proportion of the labour force with basic, secondary, general and primary education in } \\
\text { the labour force, percentage }\end{array}$ & 19,6 & 15,6 & 14,6 \\
\hline Share of unproductive workers in the self-employed & 10,4 & 9,3 & 8,9 \\
\hline
\end{tabular}


According to the data of the Bureau of National Statistics of the Agency for Strategic Planning and Reforms of the Republic of Kazakhstan, the unemployment rate among the active countries of the Eurasian Commonwealth is ranked first in terms of the number of workers by Armenia - 19,2\%, followed by Ukraine - 8\%, Kazakhstan and Azerbaijan - 4.8\%. The lowest unemployment rate in Moldova is 4.3\% (Figure 3).

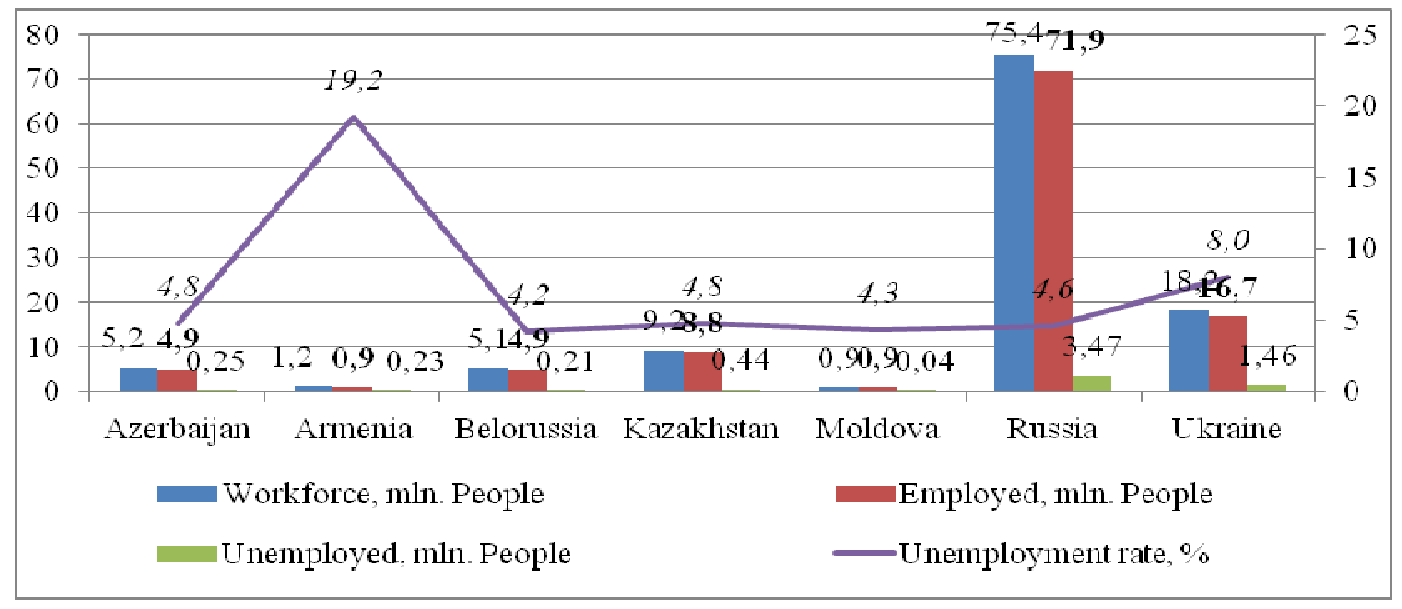

Figure 3. The labour market situation in 2019 among EU countries

Note: compiled by the authors according to the data of the source: Oficial'nyj sajt Komiteta po statistike Ministerstva nacional'noj ekonomiki RK [Official website of the Statistics Committee of the Ministry of National Economy of the Republic of Kazakhstan]

To complete the estimation of the unemployment rate in the countries of the Eurasian Union, let us give an analysis for 3 years, from 2017 to 2019, the data were also provided by the official website of the Statistical Agency of the Republic of Kazakhstan (Figure 4).

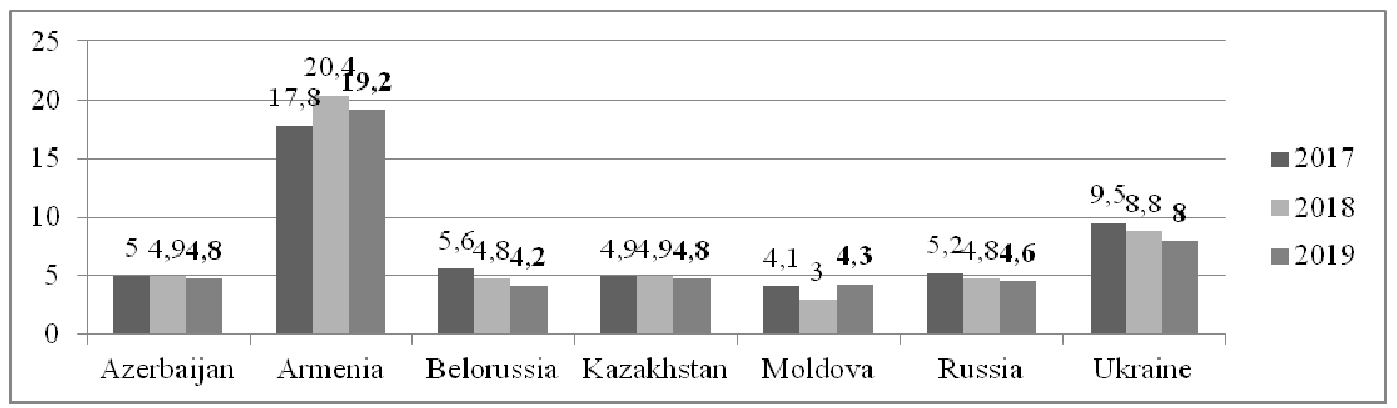

Figure 4. EU unemployment rate 2017-2019, \%

Note: compiled by the authors according to the data of the source: Oficial'nyj sajt Komiteta po statistike Ministerstva nacional'noj ekonomiki RK [Official website of the Statistics Committee of the Ministry of National Economy of the Republic of Kazakhstan]

According to the statistics, the unemployment rate in 2019 in the EU countries decreased by $6 \%$ on average, without the Republic of Moldova. In Moldova, the unemployment rate rose by $43.3 \%$. Belarus $(12.5 \%)$ and Ukraine $(9.1 \%)$ showed a sharp decline. In Kazakhstan, the decrease was only $2 \%$.

Studies have shown that in each of the EU countries there is a unique labour market, for example: influenced by various factors such as the sectoral structure of the economy, population density, migration processes, level of training, activity of enterprises, Public sector activities, etc. This explanation can also be applied to every region in our country.

To sum up, it is necessary to identify the main causes of unemployment among the younger generation on the State labour exchange: the inadequacy of the concept of the distribution of graduates of higher educational establishments to jobs; According to the qualifications obtained, and also distinguishing between the required specialties on the labour market and those of graduates. In order to address youth unemployment, international experts insist that remote work must be developed in a digital environment, and small and medium-sized enterprises are the main source for developing countries. Accordingly, to focus interest on the revitalization of the private sector. The supplement requires assistance to travel to a territory where there is a shortage of labour or vice versa. 
In the same way, the State Programme for the Development of Productive Employment and Mass Entrepreneurship for 2017-2021 «Enbek» is being implemented. Moreover, together with these active measures of state support to the young generation of the country on the instructions of the First President of RK N.A. Nazarbayev, voiced at the event with the purpose of the statement «Year of Youth» On January 23, 2019, this year it is planned to launch the National Youth Support Project «Zhastar El Tiregi» with a coverage of 1 million. young people for three years. The programme takes into account the expansion of State support through job placement, the improvement of the quality of education and the development of entrepreneurship among young people and low-income large families.

Thus, the target indicators of the State Programme for the Development of Productive Employment and Mass Entrepreneurship for 2017-2021 «Enbek» are oriented in the following four directions.

1) Short-term vocational training for participants in the VE programme;

2) Business optimization and development;

3) By optimizing employment and labour mobility, improving the situation on the labour market;

4) Tasks aimed at realization of the national project «Zhastar - El Tiregi».

In line with the objectives set, the following tasks are being carried out in the first area of short-term vocational training for participants in the VE programme:

The creation of a pool of trainees within the framework of Tipo, based on the demand of the labour market;

Vocational training courses in trades required by the labour market;

The personnel of the project «Mangilik El Zhastary- industriaga!»;

Intensive work on retraining and further training courses, including jobs to be reduced.

For the purpose of optimization and business development, the following range of tasks is specified:

- with the assistance of the regional chambers of entrepreneurs and NTP «Orley» training in the basics of entrepreneurial activity in the field of realization of the project «Bastau Business»;

In order to stimulate the financial demand for credit resources, affordable microcredit facilities for entrepreneurs in small towns and rural areas of the country should be made available.

In line with the third trend - optimization of employment and labour mobility - the improvement of the situation on the labour market is aimed at:

Assistance in finding employment for persons from low-income families with many children, persons bringing up children with special needs, young people who are not working or studying and part of the population determined by the Government;

Assistance in activating the mobility of the country's labour force;

- activation of the activity of the government Internet resource «Labour Exchange».

The main tasks aimed at the realization of the national project «Zhastar - El Tiregi» contain the following set of measures:

- active activity, expansion and development of the youth project «Zhas Kasipker»;

- within the framework of the project «Zhas Maman» providing the labour market with the most demanded personnel on the principle of 100/200.

- In this way, the government regulation of the Labour Exchange implies the concept of state bodies, measures, projects, legislative and regulatory acts, a set of instruments of monetary, social, tax policy, employment policy, aimed at ensuring the full functioning of the labour market and ensuring equal opportunities for all citizens to exercise their right to work and to free choice of employment. The regulation of the labour market is in most cases determined by the strategically well-defined objectives of the employment programmes, which are determined by the leadership of the State on the basis of the specific organization and functioning of the labour market.

Due to recent events, the world labour market is undergoing global changes. The greatest impact on this process is the shift to remote work.

The lucky ones are the ones who were transferred to remote work under the previous conditions. Those whose activities are inextricably linked to computer work - designers, video editing, programmers, copywriters, SMM managers (social networking), university professors, operators and other people working intellectually and creatively can safely work from home. However, since the crisis has affected all of us, there may be a problem of lack of demand.

Of course, not all work can be done by remote access, but unfortunately some professions have become somewhat irrelevant, for example: tour operator, tour guide, secretary, advertising manager, stylist, fitness coach, tamada. 
Tourism has been severely affected by the pandemic - travel is out of the question within closed borders. Consequently, air transport staff have also found themselves in a difficult position. Advertisers receive fewer orders every day. Not to mention entertainers. Due to the existing restrictions on the conduct of cultural-mass events, the leading celebrations, «beauty artists» - stylists, makeup artists, fitness coaches are left without work.

According to Jobeka experts - this is the Kazakhstan job search site, the most popular job vacancies in the labor market after the pandemic will be the following:

1 The crisis manager is the manager of the highest class, who identifies the weak and the strong in the business, develops a series of activities aimed at overcoming the crisis with minimal losses.

2 Programmer - develops computer programs using algorithms. The need to develop and maintain software for the sale of products/services, which is what the programmer does, increases as far as remote work is concerned.

3 The organiser of VR/AR-translations is a specialist who transforms any real event into virtual with creation of «presence effect». During the quarantine, video broadcasts at various venues have become a real rescue for artists - actors and musicians can delight their fans with performances without leaving their homes.

4 Copywriter - writes informative and selling texts to order for various sites for further publication on the Internet. A sure sign of trying in this profession is the ability to express your thoughts orally and in writing.

5 The virus tester is a volunteer who is injected with strains into the blood. The physicians monitor the course of the disease in the ward and test the patient's body with a vaccine.

6 Call center operator - deals with sales of goods / services, consulting clients by phone calls. Anyone can learn this profession if they wish. The skills required for «working on the phone» are available to secretaries, clerks, journalists.

7 An online trainer is a specialist who gives people knowledge in a particular field individually or in a group.

8 Courier - specialist in the delivery of correspondence, goods from point A to point B.

Nowadays, programmers are a very popular profession, on the labor market. Their share in remote employment is $42 \%$ in Kazakhstan, followed by $18 \%$ in the Customer Support Service (Figure 5).

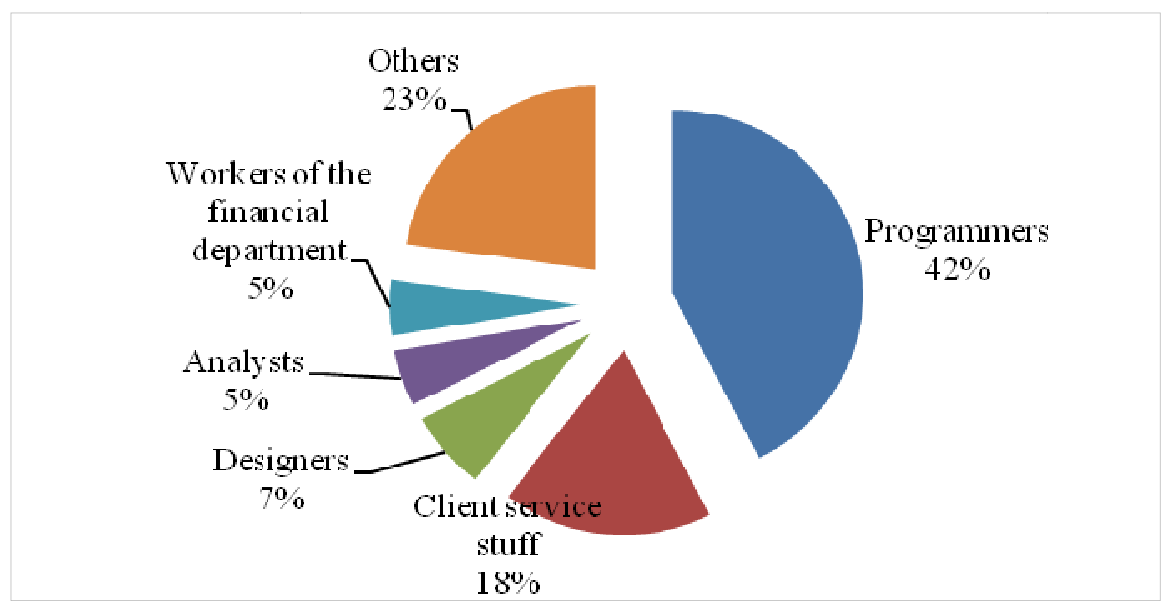

Figure 5. Occupations for people at distance working

Note: compiled by the authors according to the data of the source: Oficial'nyj sajt Komiteta po statistike Ministerstva nacional'noj ekonomiki RK [Official website of the Statistics Committee of the Ministry of National Economy of the Republic of Kazakhstan]

Entrepreneurs everywhere are moving into remote work. The reason for this is not so much the threat of the virus as the obvious lack of funds to pay for the rental of the offices.

At the end of the pandemic, many businessmen will seriously consider leaving things as they are - each member of a reduced team will do work from home. If such a possibility exists, theoretically under the prevailing conditions it is one of the best solutions for «survival» of the case. 
It is possible that when the country recovers from the destructive power of Covid-19, people will face the challenge of finding work. A large number of applicants for one post, even one not previously requested, would result in lower salaries. Graduates without work experience will be the most vulnerable.

Employers were understandably willing to avoid additional costs in a crisis, which meant that informal arrangements would become even more common. The reluctance of entrepreneurs to pay their income to the Treasury could lead to a rise in the State's income tax rate on individuals.

People who have learned new professions will not want to return to the old ones or will not be able to do so. They may no longer exist as they do. The new knowledge gained is more extensive, and those who are about to become self-study will certainly benefit, especially if it comes to information technology.

The State therefore bears even greater responsibility for the future of the country and its population. It is necessary to consider a number of turns of events in order to have several options for solving problems, and to minimize negative consequences both for the citizens of the country and for the Republic as a whole.

\section{Results}

Significant changes are taking place in the labour market, thanks to the introduction of new technologies in knowledge management systems and career development. At the same time, economic restructuring has created qualitatively different patterns in personnel management practices, updating the principles of synergy of human capital elements. In the context of the new digital information economy, the role of «soft» management technologies as a factor for the potential infinite growth of the efficiency of management systems is being increased, expressed as a departure from the functional-Administrative model of labor coercion and transition to the so-called «economy of participation», purposeful for formation of direct interest of employees in labor results and participation in management processes.

Analysis has shown that, to date, State regulation of employment policies in our State has been organized through development programmes. The central executive bodies responsible for drawing up and implementing State and Government programmes monitor job creation and submit the relevant information to the authorized employment agency.

Labour exchange regulatory programmes include:

- programmes to maintain employment growth and increase the number of jobs;

- programmes aimed at training and retraining the labour force;

- employment promotion programmes;

- unemployment insurance programmes, such as the allocation of funds for unemployment benefits.

The priority task of these programmes is to implement active forms of employment aimed at developing initiative, enterprise, professional level and territorial and social mobility of the labour market labour force.

\section{Conclusion}

In summary, we can conclude that digitization is one of the priorities of the country's economy today. Digital technologies have become firmly embedded in the modern business space, affecting all spheres and stages of production, and the conditions of the pandemic have forced the restructuring of the existing business model in Kazakhstan. The automation and robotization of a number of technological operations can lead to structural changes in the labour market and changes in the type of employment of individual professionals. There is a need to review the entire business cycle: digitization of business processes, adoption of platform solutions, introduction of artificial intelligence, etc. These changes will trigger development even in the current crisis conditions. An example is the experience of companies that were able to continue their operations during the pandemic through the re-engineering of existing business processes and the outposting of staff. Of course, for many diggings, this transition is more difficult because of the high cost of IT solutions and the complexity of moving processes to the digital sphere, but a gradual transition will allow business to remain competitive.

Finally, the process of recruitment itself is changing in a digital economy. In the future, the human resources manager is expected to be the analyst in charge of collecting and processing large databases and making key decisions. And the collection of data on the Internet through open-source information is done by a robot. And it's not fantasy anymore, it's reality. The startup Stafory already today completely replaces the recruiter: artificial intelligence (AI) «Scans» resume on recruiting sites, data from social networks, performs primary callings of candidates, conducts interviews with them with a human voice, Supplements the summary, prepares recruitment recommendations and transmits them to the personnel services of companies.

Today, the $\mathrm{Z}$ generation, the generation of people that emerged after 2000 , is entering the labor market. The characteristic feature of this generation is high technological efficiency and adaptability to new technol- 
ogies. Important for this generation is the model of target behavior at work, the existence of career values, the desire for recognition of work results, as well as high income. Therefore, companies seeking to attract and retain new types of workers need to develop tools to ensure that they benefit from capabilities.

\section{Complementary data}

The work was carried out within the framework of the state grant of the Science Committee of the Ministry of Education and Science of the Republic of Kazakhstan (IRN AP08956088 «Digital Entrepreneurship: How the Pandemic Transforms Forms of Employment in Kazakhstan»).

\section{References}

Ali M.A., Hoque M.R. \& Alam K. (2018). An empirical investigation of the relationship between egovernment development and the digital economy: The case of Asian countries. Journal of Knowledge Management, 22 (5), 1176-1200. https://www.emeraldinsight.com/doi/abs/10.1108/JKM-10-2017-0477

Australian Government. Digital Sourcing Policies (2019). Retrieved from: https://www.dta.gov.au/help-and-advice/ictprocurement/digital-sourcing-framework-ict-procurement/digital-sourcing-policies/digital-sourcing-consider-firstpolicy

Brynjolfsson, E. \& Collis, A. (2019). How should we measure the digital economy? Harvard Business Review, 97 (6), 140-146. https://hbr.org/2019/11/how-should-we-measure-the-digital-economy

Curran, D. (2018). Risk, innovation, and democracy in the digital economy. European Journal of Social Theory, 21 (2), 207-226. https://journals.sagepub.com/doi/abs/10.1177/1368431017710907

Digital Dividends: World development report (2019). Retrieved from: http://www.worldbank.org/en

Gomber, P., Kauffman, R.J., Parker, C. \& Weber, B.W. (2018). On the fintech revolution: Interpreting the forces of innovation, disruption and transformation in financial services. Journal of Management Information Systems, 35 (1), 220-226. https://www.researchgate.net/publication/324119771

Mergel I., Edelmann N. \& Haug N. (2019). Defining digital transformation: Results from expert interviews. Government Information Quarterly, 36(4). 101385. Retrieved from: https://www.sciencedirect.com/science/article /pii/S0740624X18304131

Taglioni D. \& Winkler D. (2016). Making global value chains work for development. World Bank Group, Washington, DC https://openknowledge.worldbank.org/handle/10986/24426

Warner K. S. \& Wäger M. (2019). Building dynamic capabilities for digital transformation: An ongoing process of strategic renewal. Long Range Planning, 52(3), 326-349. Retrieved from: https://www.sciencedirect.com/science/article /pii/S0024630117303710

Abdrahmanova, G.I., Vishnevskij, K.O. \& Gohberg, L.M. (2019) Chto takoe cifrovaya ekonomika? Trendy, kompetencii, izmerenie: Doklady XX Mezhdunarodnoj nauchnoj konferencii po problemam razvitiya ekonomiki i obshchestva [What is the digital economy? Trends, competencies, measurement: Reports of the XX International Scientific Conference on Problems of Economic and Social Development]. Moscow: Izdatelskii dom Vysshej shkoly ekonomiki [in Russian].

Gosudarstvennaya programma razvitiya produktivnoj zanyatosti i massovogo predprinimatel'stva «Enbek» na 20172021 gody (2018) [State Program for the development of productive Employment and Mass Entrepreneurship "Enbek" for 2017-2021]. Retrieved from: http://adilet.zan.kz/rus/docs/P1800000746 [in Russian].

Gosudarstvennaya programma razvitiya regionov na 2020-2025 gody (2019). [The state program of development of regions to 2020 - 2025]. Retrieved from: http://adilet.zan.kz/rus/docs/P1900000990 [in Russian].

Zholdaskysy, Z. (2019) Analiz prichin i posledstvij beraboticy v Kazahstane [Analysis of the causes and consequences of berabotica in Kazakhstan]. Retrieved from: https://cabar.asia/ru/analiz-prichin-i-posledstvij-bezrabotitsy-vkazahstane [in Russian].

Internet resurs po poisku vakansij [Online resource for job search]. Retrieved from: https://kz.jobeka.com/about-us [in Russian].

Kojshybaeva, M. (2019) Ocenka finansirovaniya proektov cifrovoj ekonomiki v Respublike Kazahstan [Evaluation of financing of digital economy projects in the Republic of Kazakhstan]. Vestnik Kazakhskogo natsionalnogo universiteta. Seriya Ekonomicheskaya - The Journal of Economic Research \& Business Administration, 4, 41 - 54 [in Russian].

Lapidus, L.V. (2019). Analiz metodik ocenki urovnya cifrovizacii cherez prizmu prioritetnosti dlya razvitiya rossijskih regionov: Lomonosovskie chteniya - 2019. Cifrovaya transformaciya dlya ukrepleniya ekonomicheskogo potenciala strany i uluchsheniya kachestva zhizni lyudej [Analysis of methods for assessing the level of digitalization through the prism of priority for the development of Russian regions: Lomonosov Readings - 2019. Digital transformation to strengthen the country's economic potential and improve the quality of people's lives]. Moscow: Nauchnoobrazovatel'nyj centr kompetencij v oblasti cifrovoj ekonomiki MGU imeni M.V. Lomonosova [in Russian].

Oficial'nyj sajt Komiteta po statistike Ministerstva nacional'noj ekonomiki RK [Official website of the Statistics Committee of the Ministry of National Economy of the Republic of Kazakhstan]. Retrieved from: https://stat.gov.kz/_[in Russian]. 
Prezidentskij paket mer: bolee 4,4 mln chelovek naznachena socvyplata $\mathrm{v} 42500$ tenge [Presidential package of measures: more than 4.4 million people were assigned a social payment of 42500 tenge]. Retrieved from: https://www.inform.kz/ru/prezidentskiy-paket-mer-bolee-4-4-mln-chelovek-naznachena-socvyplata-v-42500tenge_a3645886_[in Russian].

Sansyzbaeva, G. \& Kalybekova, D. (2019). Analiz i ocenka ekonomicheskih modelej ispol'zovaniya i razvitiya cifrovogo prostranstva na primere Evrazijskogo ekonomicheskogo soyuza [Analysis and evaluation of economic models for the use and development of digital space on the example of the Eurasian Economic Union]. Vestnik Kazakhskoho natsionalnoho universiteta. Seriya Ekonomicheskaya - The Journal of Economic Research \& Business Administration, 3, 78 - 88 [in Russian].

Strategicheskij plan razvitiya Respubliki Kazahstan do 2025 goda [Strategic Development Plan of the Republic of Kazakhstan until 2025]. Retrieved from: http://adilet.zan.kz/rus/docs/U1800000636 [in Russian].

Tulegenova, M. \& Tulejbaeva, A. (2019). Transformaciya rynka truda v Kazahstane v usloviyah perekhoda k cifrovoj ekonomike [Transformation of the labor market in Kazakhstan in the context of the transition to the digital economy]. Vestnik Kazakhskogo natsionalnogo universiteta. Seriya Ekonomicheskaya - The Journal of Economic Research \& Business Administration, 1, 266-273 [in Russian].

Umnova, M.G. \& Busalova, A.D. (2020). Obzor tendencij v cifrovizacii predprinimatel'stva i menedzhmenta [Overview of trends in the digitalization of entrepreneurship and management] Ekonomika, predprinimatel'stvo i pravo - Economics, Entrepreneurship and Law, 10 (6), 1689 - 1700 [in Russian].

Ustinova, N.G. (2019). Cifrovaya ekonomika i predprinimatel'stvo: voprosy vzaimodejstviya [Digital economy and entrepreneurship: issues of interaction] Vestnik SGSEU. 3 (77), 32 - 37 [in Russian].

Carikovskij, A.Yu. (2018). Antimonopol'noe regulirovanie v cifrovuyu epohu: kak zashchishchat' konkurenciyu v usloviyah globalizacii i chetvyortoj promyshlennoj revolyucii [Antitrust regulation in the Digital Age: how to protect competition in the context of globalization and the fourth industrial revolution]. Moscow: Izdatelskii dom Vysshej shkoly ekonomiki [in Russian].

\section{С.Н. Суйеубаева, Э.С. Мадиярова, Г.Б. Пестунова}

\section{Еңбек нарығын дамытудың қазіргі тенденцияларын зерттеу: цифрлық технологиялар мен COVID-19 пандемиясының әсерінен болған өзгерістер}

Аңдатnа

Maқ̧cambl: Цифрлық экономика және COVID-19 пандемиясы жағдайындағы еңбек нарығының қазіргі жағдайы мен басымдықтарын зерттеу.

Әдісі: Зерттеудің теориялық негізі - еңбек нарығын цифрландыру мәселелері бойынша отандық және шетелдік ғалым-экономистердің еңбектері, Қазақстан Республикасының заңнамалық және нормативтік актілері. Зерттеудің ақпараттық негізі Қазақстан Республикасы Экономика министрлігі Статистика комитетінің мәліметтері және авторлардың зерттеу нәтижелері. Зерттеудің әдіснамалық негізі экономикалық процестерді зерттеудің жүйелі тәсілі, абстрактілі-логикалық, экономикалық-статистикалық, монографиялық әдістер болып табылады.

Қорытынды:: Мақалада Қазақстан Республикасының еңбек нарығының дамуын шет елдермен салыстыра отырып, талдау нәтижелері келтірілген. Цифрлық экономика және КОРОНА дағдарысы жағдайында жұмыспен қамту мәселелері қарастырылды. Цифрлық технологияларды енгізу жылдамдығы неғұрлым тез болса, цифрлық экономиканың қалыптасуын басқару міндеттері соғұрлым күрделі болатындығы атап өтілген. Технологиялар жаңа өндірістерді дамытудың қозғалтқышына айналып қана қоймай, сонымен бірге маңызды әлеуметтік рөлдерге ие болып, халықтың қартаюы, әлеуметтік теңсіздік, экологиялық мәселелер және климаттың өзгеруі сияқты әлеуметтік мәселелерді шешуге зор үлес қосуда. Дамыған ғылым мен техниканың көмегімен адамның қажеттіліктеріне, икемділігі мен шығармашылығына бағдарлаудың жаңа құндылықтарына негізделген «ақылды» қоғам қалыптасуда. Цифрландырудың әсерінен еңбек нарығы, денсаулық сақтау, білім беру және кеңістікті дамыту түбегейлі өзгеруде.

Тұжырымдама: Мақалада цифрландыру тұрғысынан Қазақстан экономикасы үшін жұмыспен қамтудың жаңа түрлерін іздеу жағдайларын қалыптастырудың негізгі аспектілері ашылған. Қазіргі жағдайда цифрлық ортаны дамытуға баса назар аударылады. «Цифрлық Қазақстан» Мемлекеттік бағдарламасы шеңберінде экономикалық субъектілерді мемлекеттік қолдаудың мазмұны қарастырылды. Пандемия жағдайында кең таралған шектеулерден әлемдік экономикада туындаған өзгерістер қазақстандық еңбек нарығында жұмыспен қамтудың жаңа жолдары мен формаларын іздеуге әкеледі деген қорытынды жасалды.

Kiлm сөздер: сандық экономика, еңбек нарығы, жұмыспен қамту, цифрландыру, пандемия. 


\title{
С.Н. Суйеубаева, Э.С. Мадиярова, Г.Б. Пестунова \\ Исследование современных тенденций в развитии рынка труда: изменения, вызванные цифровыми технологиями и пандемией COVID-19
}

\begin{abstract}
Аннотация
Цель: Изучение современного состояния и приоритетов развития рынка труда в условиях цифровой экономики и пандемии COVID-19.

Meтодbl: Теоретической основой исследования являются произведения отечественных и зарубежных ученых-экономистов по проблемам цифровизации рынка труда, законодательные и нормативно-правовые акты Республики Казахстан. Информационную основу исследования составили данные Комитета по статистике Министерства экономики Республики Казахстан и результаты исследований авторов. Методологической основой исследования являются системный подход, абстрактно-логический, экономико-статистический, монографический методы изучения экономических процессов.

Pезультаты: В статье приведены результаты анализа развития рынка труда Республики Казахстан в сравнении с зарубежными странами. Рассмотрены вопросы занятости в условиях цифровой экономики и CORONA-кризиса. Отмечено, что чем быстрее темп внедрения цифровых технологий, тем сложнее задачи управления становлением цифровой экономики. Технологии становятся далеко не только двигателем развития новых отраслей, но и обретают важные социальные роли, внося значимый вклад в решение проблем общества, таких как старение населения, социальное расслоение, экологические проблемы и изменение климата. С помощью передовой науки и технологий возникает «умное» общество, базирующееся на новых ценностях ориентации на потребности человека, гибкости, креативности. Под влиянием цифровизации кардинально меняются рынок труда, здравоохранение, образование, пространственное развитие.

Bblвoдbl: Статья раскрывает ключевые аспекты формирования условий для поиска новых форм занятости для казахстанской экономики с позиции цифровизации. Акцент делается на развитии цифровой среды в современных условиях. Рассмотрено содержание государственной поддержки экономических субъектов в рамках государственной программы «Цифровой Казахстан». Сделан вывод, что изменения, вызванные в мировой экономике повсеместными ограничениями в условиях пандемии, приведут к поиску новых путей и форм занятости на казахстанском рынке труда.
\end{abstract}

Ключевые слова: цифровая экономика, рынок труда, занятость населения, цифровизация, пандемия.

\section{References}

Ali M.A., Hoque M.R., Alam K. An empirical investigation of the relationship between egovernment development and the digital economy: The case of Asian countries / Ali M.A., Hoque M.R., Alam K // Journal of Knowledge Management. — 2018. — № 22 (5). — P. 1176 - 1200. https://www.emeraldinsight.com/doi/abs/10.1108/JKM-102017-0477

Australian Government. Digital Sourcing Policies — 2019. Retrieved from: https://www.dta.gov.au/help-andadvice/ict-procurement/digital-sourcing-framework-ict-procurement/digital-sourcing-policies/digital-sourcingconsider-first-policy

Brynjolfsson E., Collis A. How should we measure the digital economy? / Brynjolfsson E., Collis A. // Harvard Business Review. — 2019. — № 97 (6). — P. 140-146. https://hbr.org/2019/11/how-should-we-measure-the-digitaleconomy

Curran D. Risk, innovation, and democracy in the digital economy // European Journal of Social Theory. — 2018. № 21 (2). — P. 207-226. https://journals.sagepub.com/doi/abs/10.1177/1368431017710907

Digital Dividends: World development report — 2019. Retrieved from: http:/www.worldbank.org/en

Gomber P., Kauffman R.J., Parker C., Weber B.W. On the fintech revolution: Interpreting the forces of innovation, disruption and transformation in financial services / Gomber P., Kauffman R.J., Parker C., Weber B.W. // Journal of Management Information Systems. — 2018. — № 35 (1). — P. 220 — 226. https://www.researchgate.net /publication/324119771

Mergel I., Edelmann N., Haug N. Defining digital transformation: Results from expert interviews // Government Information Quarterly. — 2019. — № 36 (4). 101385. Retrieved from: https://www.sciencedirect.com/science/article/pii /S0740624X18304131

Taglioni D., Winkler D. Making global value chains work for development. World Bank Group. — Washington: DC, 2016 https://openknowledge.worldbank.org/handle/10986/24426

Warner K. S., Wäger M. Building dynamic capabilities for digital transformation: An ongoing process of strategic renewal // Long Range Planning. - 2019. - № 52 (3). - P. 326 - 349. Retrieved from: https://www.sciencedirect.com/science/article/pii/S0024630117303710

Абдрахманова Г.И., Вишневский К.О., Гохберг Л.М. Что такое цифровая экономика? Тренды, компетенции, измерение: Докл. ХХ Междунар. науч. конф. по проблемам развития экономики и общества. - М.: Изд. дом Высшей школы экономики, 2019. - 82 с. 
Государственная программа развития продуктивной занятости и массового предпринимательства «Еңбек» на 2017-2021 годы. — Режим доступа: http://adilet.zan.kz/rus/docs/P1800000746

Государственная программа развития регионов на 2020-2025 годы. — Режим доступа: http://adilet.zan.kz/rus/docs/P1900000990

Жолдасқысы 3. Анализ причин и последствий беработицы в Казахстане / 3. Жолдасқысы. - Режим доступа: https://cabar.asia/ru/analiz-prichin-i-posledstvij-bezrabotitsy-v-kazahstane

Интернет ресурс по поиску вакансий. - Режим доступа: https://kz.jobeka.com/about-us

Койшыбаева М. Оценка финансирования проектов цифровой экономики в Республике Казахстан / М. Койшыбаева // Вестн. Казах. нац. ун-та. Сер. экон. — 2019. — № 4. — С. 41-51.

Лапидус Л.В. Анализ методик оценки уровня цифровизации через призму приоритетности для развития российских регионов: Ломоносовские чтения - 2019. Цифровая трансформация для укрепления экономического потенциала страны и улучшения качества жизни людей / Л.В. Лапидус. - М.: Науч.-образов. центр компетенций в области цифровой экономики МГУ им. М.В. Ломоносова, 2019.

Официальный сайт Комитета по статистике Министерства национальной экономики РК. — Режим доступа: https://stat.gov.kz/

Президентский пакет мер: более 4,4 млн человек назначена соцвыплата в 42500 тенге. - Режим доступа: https://www.inform.kz/ru/prezidentskiy-paket-mer-bolee-4-4-mln-chelovek-naznachena-socvyplata-v-42500tenge_a3645886

Сансызбаева Г. Анализ и оценка экономических моделей использования и развития цифрового пространства на примере Евразийского экономического союза / Г. Сансызбаева, Д. Калыбекова // Вестн. Казах. нац. ун-та. Сер. Экономическая. - 2019. - № 3. - С. 78-88.

Стратегический план развития Республики Казахстан до 2025 года. — Режим доступа: http://adilet.zan.kz/rus/docs/U1800000636

Тулегенова М. Трансформация рынка труда в Казахстане в условиях перехода к цифровой экономике / М.Тулегенова, А. Тулейбаева // Вестн. Казах. нац. ун-та. Сер. экон. — 2019. — № 1. — С. $266-273$.

Умнова М.Г. Обзор тенденций в цифровизации предпринимательства и менеджмента / М.Г. Умнова, А.Д. Бусалова // Экономика, предпринимательство и право. - 2020. - 10 (6). — С. 1689-1700.

Устинова Н.Г. Цифровая экономика и предпринимательство: вопросы взаимодействия // Вестн. СГСЭУ. 2019. — № 3 (77). - С. 32-37.

Цариковский А.Ю. Антимонопольное регулирование в цифровую эпоху: как защищать конкуренцию в условиях глобализации и четвёртой промышленной революции. - М.: Изд. дом Высш. шк. экон., 2018. - 311 с. 